\title{
Professional Teacher for EFL Classroom
}

\author{
Fahriany $^{\text {a }}$, Fahri Haswani ${ }^{\text {b }}$ \\ ${ }^{a}$ Syarif Hidayatullah State Islamic University Jakarta, J1. Ir. H. Djuanda 95, Ciputat, Indonesia \\ bState University of Medan, Medan, Indonesia \\ Corresponding e-mail: fahriany@uinjkt.ac.id
}

\begin{abstract}
One factor influencing the success of EFL Class is teachers, which of course are expected to have good competences. One of the required competences is professionalism beside pedagogical personality and social competences. This article discusses professional English teachers who can inspire students to be motivated to learn English well. It includes how the English teachers motivate and inspire students. Inspiring teachers have quite distinct personal qualities, kindness, patience, and are able to build mutual relationship between students and teachers. This study was carried out at English Education Faculty of Educational Sciences UIN Syarif Hidayatullah Jakarta. Data of this study were taken from student who had taken subject in their odd smester. Their perception are the representation of their judgement made based on their learning experience. The open ended questionnaire was functioned of data collection technique. Students were given enough time to express their judgement on their English language teachers. The result shows that teachers are the main source of language available to students, their richer knowledge of and better proficiency in the language can help learners to overcome their difficulties in communicative skills.
\end{abstract}

Keywords: teacher, professional, EFL classroom

\section{INTRODUCTION}

Good and qualified teachers are essential for efficient functioning of educational systems and for enhancing the quality of learning. Research supports this notion that a good teacher and actions to be taken on his part in the classroom play a vital role in provoking effective and efficient learning on the part of the students (Markley, 2004). Teachers also have a fundamental role in their learners' academic achievement and their quality can highly influence student outcomes (Campbell, Kyriakides, Muijsc \& Robinsona, 2004; Lasley II, Siedentop \& Yinger, 2006; Rockoff, 2004).

English language teachers are by no means an exception and their key role in effective language learning cannot be overlooked. Special attention must be paid to this link between teachers and learners in countries like Iran where language learning happens mainly in formal classroom settings (Kariminia \& Salehizadeh, 2007), and teachers, as the main source of language input to students, affect their learning directly. Although effective teachers in general may share some characteristics, there are certain qualities that differ among them depending on the subject matter they teach.

Some researchers believe that it is the nature of the subject matter thatmakes language teachers different from teachers of other fields (Hammadou \& Bernhar, 1987). Some others even go beyond this and claim that diverse subject matters are not the only distinction between teachers of various subjects (Borg, 2006). Rather a teacher's beliefs, perceptions and assumptions about teaching and teacher efficacy affect the way he/she understands and organizes instruction (Chacón, 2005). It is also important to study the perceptions of learners about learning and teaching. Their beliefs about language learning seem to have obvious relevance to understanding their expectations of the course, their commitment to the class as well as providing them with the opportunity to be successful and satisfied with their language learning program (Horwitz, 1988). Moreover, investigation of the student beliefs about different behaviors in the language classroom is useful in 
informing teachers about different types of learners that need to be catered for (Cotterall, 1999).

Some clues can be gleaned from previous research about the qualities of a good and effective language teacher. Pettis (1997) identified three main characteristics for a professionally competent teacher. According to her, an effective teacher must firstly be principled and knowledgeable in addition to being skillful. Secondly, professional needs and interests of an effective language teacher must change over time and develop during his/her teaching. Thirdly, a teacher must be personally committed to his/her professional development.

In an attempt to understand what it means to be a foreign language teacher and in what sense they are different from other teachers, Borg (2006) examined the definitions of over 200 practicing and prospective English language teachers from a variety of contexts about the distinction between language teachers and those of other fields. His analysis also included the opinions of mathematics, history, science and chemistry teachers on the extent to which characteristics claimed to be distinctive of language teachers applied to their own subjects. His participants believed that subject matter and the medium were the same in language teaching and that there was no clear distinction between them as in other subjects.

Moreover, language teachers inducted learners into ways of thinking and being which reflect those of the target culture. In terms of content, language teaching was regarded to be more complex and varied than other subjects. In terms of methodology, in the afore-mentioned study, the methods, the activities and the material used by or available to English language teachers were reported to be different from those in the other subjects. It was also found that English language teaching methodology was more progressive than that of other subjects, and consequently, English language teachers needed to be more up-to-date to cope with advanced and progressive nature of language teaching methodology.

English language teachers were also supposed to have closer, more relaxed, and generally more positive relationships with learners in comparison to other teachers. One further source of distinction between English language teachers and teachers of other fields was that the former's language proficiency and command of the language was usually compared to that of native speakers of the target language (Borg, 2006). However, it is not clearly stated if this final point is a merit or a demerit for language teachers.

Effective language teachers have been described in the literature as having not only a profound competence in the target language but a set of personal qualities like sensitivity, warmth and tolerance (Vadillio, 1999). In an investigation of the characteristics of good language teachers, Brosh (1996) found the desirable characteristics of an effective language teacher to be: having knowledge and command of the target language; being able to organize, explain, and clarify, as well as to arouse and sustain interest and motivation among students; being fair to students by showing neither favoritism nor prejudice; and being available to students. Both language teachers and learners counted command of the target language and teaching comprehensibility as the most important characteristics to be possessed by an effective foreign language teacher. Moreover, the teachers gave more weight to items related to developing motivation and research orientation, whereas the students counted items relating to treating students fairly and making lessons interesting more important as compared with the teachers' ideas on these very issues.

Research has recently been conducted on the development of standards in Foreign Language Teacher Preparation in Croatia (Kalebic, 2005). As a result, possession of fourteen competences was reported to be needed by would-be language teachers. Those characteristics reported to be highly valuable for a beginning language teacher were: linguistic and communicative competence; communication and presentation skills; ability to motivate learners for learning; ability to choose appropriate teaching strategies; ability to deal with unpredictable situations and to maintain discipline; ability to plan the lesson; ability to organize learning activities; ability of pedagogical action; ability to create friendly atmosphere in the classroom; ability to respond to learner abilities and needs (flexibility); knowledge about teaching strategies; knowledge about the culture and literature in of the target language; ability to assess learner language knowledge/competence; and knowledge of methods and theoretical concepts in English language teaching (Kalebic, 2005).

And finally, Park and Lee (2006) investigated the characteristics of effective English teachers as perceived by teachers and students in high schools in Korea, with a self-report questionnaire consisting of three categories: English proficiency, pedagogical knowledge, and socio-affective skills. Their findings indicated that on the whole the teacher's perceptions of characteristics important for an English language teacher to possess differed significantly form those of the students in all three categories, with the teachers ranking English proficiency the highest and the students ranking pedagogical knowledge the first.

Although most of the research conducted on the qualities of a good teacher (a small sample of which 
was reported above) has mainly focused on teachers' perceptions only and although there has been little work of comparative nature where the views of both teachers and learners have been compared, knowing about what other stake-holders (including learners, parents and authorities) expect from teachers will greatly contribute to effective fulfillment of teachers' duties.

No doubt, learners are the most important individuals for teachers to cater for (since without learners, there will be no teachers), and understanding their expectations as who a good teacher is will of course help teachers to rethink the techniques they use for teaching, especially if learners' views show teachers that each learner is a unique person with his/her unique likes, dislikes, preferences and learning styles. As such, the ideas and opinions of learners will help teachers to better live up to the expectations of the most important stake-holders in a teaching-learning process (Sadeghi and Babai, 2009). This paper, accordingly, furthers our understanding of the teacher-student relationships by investigating characteristics of an effective English language teacher from the perspective of both teachers and learners.

\section{METHOD}

This study was carried out at English Education Faculty of Educational Sciences UIN Syarif Hidayatullah Jakarta. Data of this study were taken from student who had taken subject in their odd smester. Their perception are the representation of their judgement made based on their learning experience. The open ended questionnaire was functioned of data collection technique. Students were given enough time to express their judgement on their English language teachers.

\section{RESULT AND DISCUSSION}

The first question was aimed to determine the characteristics of professional English language teacher. The second question asked them about the possible differences between English language teachers and teachers of other subject areas. Answers to each question were analyzed independently.

The learners regarded the following as desirable characteristics of professional English language teacher apart from those cited above in the quantitative part: being patient and flexible, caring about the students' needs, having positive attitudes towards the learners and being smart and creative.
However, the students mentioned a point which was completely ignored by the teachers and which may be not so welcome for teachers.

According to the learners, besides the characteristics mentioned above, being to the point and not speaking a lot about one's personal experiences was a characteristic of a professional teacher. As an answer to this question, one of students wrote, "Professional English language teachers must be open minded and use a variety of methods in teaching without sticking to a particular method. They must also have a positive view toward their students." And a teacher, as an example, commented, "He should be optimistic. He should also welcome student's mistakes and try to put himself in his students' shoes."

Regarding the differences between English language teachers and those of other subject matters, both groups counted being familiar with a foreign language and culture and teaching in a medium other than students' mother tongue as the most important distinctive feature between English language teachers and those of other subject areas. : "English language teachers differ from teachers of other subjects in that they teach a language other than the learners' mother tongue and are therefore familiar with a foreign culture. They are the only source of that language available to their students."

Although the teachers regarded being up-to-date as a favorable characteristic of prfessional English language teacher, they did not consider it exclusive to English language teachers. In other words, they perceived being up-to-date as a factor affecting a teacher's efficacy but not as being a distinctive characteristic of English language teachers.

The findings show learners of English hold different views toward some characteristics of professional English language teacher. As Pettis (1997) notes, professionally competent English teachers are profoundly knowledgeable in language. This also confirms the findings of Calabria (1960), Feldman (1976) and Feldman (1988) who had founded mastery of subject matter as a characteristic of professional teacher. On the whole, the teachers perceived features like high knowledge of pedagogy and the use of particular techniques and methods such as preparing the lesson well, using lesson plans, unbiased assessment of what students have learned, integrating group activities to class and assigning homework to be possessed by professional English language teachers.

However, the learners assigned more weight to characteristics relating to a teachers' personality and the way he behaves his students. Moreover, whereas the teachers only concentrated on the positive characteristics of professional teacher, such as being patient, being flexible and caring about students' 
needs, being optimist and having positive attitude toward the students, and being smart and creative, the students considering these positive qualities important focused also on the characteristics that may affect a teacher's efficacy adversely like speaking a lot about his/her personal experiences.

All these indicate that teachers look at an effective teacher from the professional point of view and their responses are more informed reflecting their knowledge and expertise on theories and methodology of language teaching. The students' perspectives also seem very realistic and the fact that they consider both strong and weak points of their teachers can help teachers to reflect on their own behaviors in the classroom and try to overcome the possible problems resulting in deficiency.

\section{CONCLUSIONS}

As teachers are the main source of language available to students, their richer knowledge of and better proficiency in the language can help learners to overcome their difficulties in communicative skills. Moreover, attending to students' needs will not only mean that teachers should seek to meet the learners' needs with regards to personality (whereby more attention must be paid to educational psychology), it will also mean that teachers will need to offer individualized instruction as far as possible in an attempt to cater for idiosyncratic learning styles of different learners. This latter concern will be taken care of more effectively if the teachers are willing to take the learners' level into account and try to use right techniques and procedures at the right proficiency level to suit their learners the best, all of which will materialize only when the teachers make themselves committed enough to their teaching duties by rigorously preparing themselves for the battlefield.

\section{REFERENCES}

Borg, S. (2006). The distinctive characteristics of foreign language teachers. Language Teaching Research, 10(1), pp. 3-31.

Brosh, H. (1996). Perceived characteristics of an effective language teacher. Foreign Language Annals, 29(2), pp. 25-38.

Calabria, F. M. (1960). Characteristics of effective teachers. Educational Research Bulletin, 39(4), pp. 92-100.

Campbell, R. J., Kyriakides, L., Muijsc, R. D. \& Robinsona, W. (2004). Effective teaching and values: Some implications for research and teacher appraisal. Oxford Review of Education, 30(4), pp. 451-465.

Chacón, C. T. (2005). Teachers' perceived efficacy among English as a foreign language teachers in middle schools in Venezuela. Teaching and Teacher Education, 21(3), pp. 257-272.

Cotterall, S. (1999). Key variables in language learning: What do learners believe about them? System, 27(4), pp. 493-513.

Crawford, J. (2004). Language choice in the foreign language classroom: Target language or the learners' first language?. RELC Journal, 35(5), pp. 5-20.

Dickinson Gibbons, J. \& Chakraborti, S. (2003). Nonparametric statistical inference. New York: CRC Press

Feldman, K. A. (1976). The superior college teacher from the students' view. Research in Higher Education, 5(3), pp. 243-288.

Feldman, K. A. (1988). Effective college teaching from the students' and faculty's view: Matched or mismatched priorities?. Research in Higher Education, 28(4), pp. 291-344.

Feldman, K. A. (1992). College students' view of male and female college teachers: Part I, evidence from the social laboratory and experiments. Research in Higher Education, 33(3), pp. 317-375.

Feldman, K. A. (1993). College students' view of male and female college teachers: Part II, evidence from students' evaluations of their classroom teachers. Research in Higher Education, 34(2), pp. 151-211

Hammadou, J. \& Bernhar, E. B. (1987). On being and becoming a foreign language teacher. Theory into Practice, 26(4), pp. 301-306.

Horwitz, E. K. (1988). The beliefs about language learning of beginning university foreign language students. The Modern Language Journal, 72(3), pp. 283-294.

Kalebic, S. C. (2005). Towards the development of standards in foreign language teacher preparation. Paper presented at 30th ATEEA (Association for Teacher Education in Europe) Annual Conference Amsterdam, Netherlands. Retrieved 1 September 2008 from www.atee2005.nl/download/papers/05_ab.pdf

Kariminia, A. \& Salehizadeh, S. (2007). Communication strategies: English language departments in Iran. Iranian Journal of Language Studies, 1(4), pp. 287-300.

Lasley II, T. J., Siedentop, D. \& Yinger, R. (2006). A systemic approach to enhancing teacher quality: The Ohio model. Journal of Teacher Education, 57(1), pp. 13-21. 
Mackey, A. \& Gass, S. M. (2005). Second language research: Methodology and design. New Jersey: Lawrence Erlbaum Associates.

Markley, T. (2004). Defining the effective teacher: Current arguments in education. Essays in Education, 11(3), pp. 1-14.

Noora, A. (2008). Iranian undergraduate nonEnglish majors' language learning preferences. GEMA Online Journal of Language Studies, 8(2), pp. 33-44.

Park, G. P. \& Lee, H. W. (2006). The characteristics of effective English teachers as perceived by high school teachers and students in Korea. Asia Pacific Education Review, 7(2), pp. 236248.

Pettis, J. (1997). Developing our professional competence; Some reflections. TESL Canada Journal, 16(2), pp. 67-71.

Polio, C. G. \& Duff, P. A. (1994). Teachers' language use in university foreign language classrooms: A qualitative analysis of English and target language alternation. The Modern Language Journal, 78(3), pp. 313-326.

Razmjoo, S. A. (2007). High schools or private institutes textbooks? Which fulfil communicative language teaching principles in the Iranian context? Asian EFL Journal, 9(4), pp. 126-140.

Rockoff, J. E. (2004). The impact of individual teachers on student achievement: Evidence from panel data. The American Economic Review, 94(2), 247-252.

Sadeghi, K. \& Babai, H. (2009). Becoming an effective English language teacher: Living up to the expectations of L2 learners and teachers of English. Saarbrücken, Germany: VDM Verlag.

Vadillio, R. S. M. (1999). Research on the good language teacher. EPOS, 15, 347-361. 